\title{
Differences in Combining CBL with GI Versus with Tutorial Methods on Activeness and Conceptual Understanding
}

\author{
Yuni Rahmawati ${ }^{1}$, Nur Dianto ${ }^{1}$ and Hari Putranto ${ }^{1}$ \\ ${ }^{1}$ Department of Electrical Engineering, Faculty of Engineering, Universitas Negeri Malang, Malang 65145 \\ Yuni.rahmawati.ft@um.ac.id, nurdiantodianto6@gmail.com, hari.putranto.ft@um.ac.id
}

\begin{abstract}
Keyword: $\quad$ Challenge Based Learning (CBL), Guided Individual (GI), Tutorial, Activity, Concept Understanding
Abstrak: $\quad$ The learning process at schools needs to be considered to improve the quality of education in order to help students preparing to face working world. The research design used was Quasi Experimental Design with a research design Non-Equivalent Control Group Design. The research subjects were class X TIPTL students of SMK 1 Kediri. The measurement instrument is a posttest for understanding concepts and observation sheets for students' activeness. The aspects measured are cognitive and affective aspects. Hypothesis testing is done by Independent Sample T-Test technique for conceptual understanding and Man Whitnee U Test for students' activeness, assisted by SPSS software. The results show that there are significant differences in the implementation of CBL model combined with guided individual and tutorial methods on students' activeness and conceptual understanding. There a differences in students' activeness with sig. $=0,000$ and in conceptual understanding with sig. $=0.010$.
\end{abstract}

\section{INTRODUCTION}

The 21 st century or also called the information era where information and communication technology is one of the main factors that affect human life in various aspects (Asmawi et al., 2014). Information can be accessed easily by anyone who is able to use the technology anytime and anywhere that unify global citizen because the boundaries between countries are increasingly invisible.

The existence of technology also influences education which causes an acceleration of a significant increase in knowledge. Eri Murti (in Asmawi 2014) states that the internet accelerated the distribution of information throughout the world. Communication, collaboration and learning activities are increasingly facilitated in the 21st century. This results in a paradigm shift in learning in the education process.

The implementation of the 2013 curriculum is an anticipation of the 21st century learning paradigm shift. The characteristics of the 21 st century include ease of obtaining information, faster computation using machines, almost all jobs using automation, and the ease of communication anytime and anywhere. Associated with 21st century characteristics of the learning model criteria that need to be applied include; (1) students are encouraged to find out from various sources rather than being told, (2) students are directed to formulate problems or ask questions not only solve problems or answer, (3) students are directed to train analytical thinking or be able to make decisions, and (4) students are encouraged to emphasize the importance of collaboration or cooperation to solve problems (Litbang Kemdikbud, 2013).

Vocational High School (SMK) as one of formal education is expected to produce high-quality resources. It is in accordance with the objectives of SMK; to help students preparing to be ready to face the challenges of the workforce (Sisdiknas Law No. 20 of 2013)

Vocational students need a variety of skills to be ready to face the challenges of the 21 st century, so they do not find it hard and are able to adapt to a challenging and competitive work environment. Susilo (2011: 8) in Partnership For 21st Century Skill formulates 21 st century skills into three general skills; (1) information and communication related skills, (2) thinking and problem solving skills, and (3) interpersonal and self-regulating skills.

One of teachers' efforts of to achieve learning goals is by choosing the right learning activities for students. Hikmah, et al. (2015) shows that there is a significant influence between the activity of students 
a Non-Equivalent Control Group Design research design such as Table 1.

Table 1. Experimental Research Plan Inspired by that statement, appropriate student activity will produce skills and help students understand the lessons.

The next learning objective is student learning completeness which is seen through learning outcomes. Novitasari, L. \& Leonard (2017) states that there is a significant influence between understanding the concept of learning outcomes. Nakhleh (in Demircioglu 2014) states that student strugle to understanding concepts but they are often unsuccessful. It can be interpreted that the increasing understanding of concepts will improve student learning outcomes.

In enhancing the activeness and understanding of students' concepts, it is important to find the right learning models and methods. Challenge Based Learning (CBL) combined with tutorial methods and CBL combined with guided individual methods are some variation of models and learning methods to be able to improve activity and concepts understanding by students. Tsuei (2011) states that peer tutoring is characterized by specific role-taking which is aimed at enhancing learning, motivation and achievement. Another research by Kastenmeier, et al (2018) finding that the individual learning plan requirement has been contribute to enchanced educational outcomes. A research by Yang (2018) finding that challenge based learning model can enhance student's ability to innovate and create.

Based on the above explanation, the objectives of this study are; (1) to describe the understanding of concepts and learning activeness because of the influence of applying CBL in combination with the tutorial method, (2) to describe the understanding of concepts and active learning because of the influence of applying CBL in combination with guided individual methods, (3) to know the significance of the difference in conceptual understanding and learning activeness because of the influence of applying CBL in combination with guided individual methods and CBL in combination with the tutorial method, and (4) to know the combination of superior models and methods.

\section{METHOD}

This research is an experimental study with a quantitative approach to analyze data. The design used in this study is a quasi-experimental design with

\begin{tabular}{|l|c|c|c|}
\hline Class & Pretest & Treatment & Posstest \\
\hline Control 1 & $\mathrm{O}_{3}$ & $\mathrm{X}_{1}$ & $\mathrm{O}_{2}$ \\
\hline erimental 2 & $\mathrm{O}_{5}$ & $\mathrm{X}_{2}$ & $\mathrm{O}_{4}$ \\
\hline Control 2 & $\mathrm{O}_{7}$ & & $\mathrm{O}_{6}$ \\
\hline
\end{tabular}

Notes:

$\mathrm{O}_{1} \quad$ : Pretest of experimental class 1

$\mathrm{O}_{2} \quad$ : Posttest of experimental class 1

$\mathrm{O}_{3} \quad$ : Prestest of control class 1

$\mathrm{O}_{4} \quad$ : Posttest of control class 1

$\mathrm{O}_{5} \quad$ : Pretest of experimental class 2

$\mathrm{O}_{6} \quad$ : Posttest of experimental class 2

$\mathrm{O}_{7} \quad$ : Prestest of control class 2

$\mathrm{O}_{8} \quad$ : Posttest of control class 2

$\mathrm{X}_{1} \quad$ : The treatment of CBL combined with the tutorial method

$\mathrm{X}_{2} \quad$ : The treatment of CBL combined with guided individual methods

The subjects of this study were students of electrical expertise programs at SMK 1 Kediri taking Basic Electricity and Electronics (DLE) subjects in the even semester. They are 31 students of class $\mathrm{X}$ TIPTL 2 who were treated with CBL in combination with the tutorial method and 30 students of class $\mathrm{X}$ TIPTL 3 who were treated with CBL in combination with guided individual methods.

There are treatment instruments and research instruments that have been validated by experts (expert judgment) and DLE subject teachers. The treatment instruments used were teaching plans (RPP), learning material, jobsheets, and media in the form of power points. The measurement instrument used was in the form of activeness observation sheet and tests.

The data analysis process consists of several stages; description of data, prerequisite test, similarity test, average scores of students' initial abilities and hypothesis testing. The processed data is data taken before and after treatment.

The first data analysis process is data description; grouping data in several categories based on Sudijono's formula (2012: 329). The range of scores obtained is as follows; (a) a very low category with a range of 15-35, (b) a low category with a range of 3649 , (c) a medium category with a range of $50-64$, (d) a high category with a range of 65-79, and (e) a very high category with a range of 80-100. homogeneity test. The normality test used the Shapiro
Prerequisite tests consisted of normality test and 
obtained from research on students who applied CBL

Wilk test. The guidelines for decision making was if the number is significant> 0.05 then the data is normally distributed, whereas if the number is significant $<0.05$ then the data is not normally distributed. The homogeneity test used Levene test. The guideline for decision making was if the significance scores is $>0.05$, the data is said to be homogeneous or have the same variant, whereas if the significance scores is $<0.05$ then the data is not homogeneous or the variance is not similar.

The three tests of similarity in the average scores of students' initial abilities were used to determine the similarity of students' initial abilities. The statistical test used was the Independent Sample $T$ Test. The guideline for decision making was if the Sig (2-tailed) scores is $>0.05$, then $\mathrm{H}_{0}$ is accepted, but if the Sig (2tailed) scores is $<0.05$, then $\mathrm{H}_{0}$ is rejected.

The hypothesis tests were used to determine the significance of differences in concept understanding and student activity because of CBL influence in combination with guided individual methods compared to $\mathrm{CBL}$ in combination with tutorial methods on vocational students. Hypothesis testing for the significance of differences in concept understanding used the Independent Sample T Test test technique. The decision-making guidelines was, if the Sig (2-tailed) scores is $>0.05$, then $\mathrm{H}_{0}$ is accepted, but if the Sig (2-tailed) scores is $<0.05$ then $\mathrm{H}_{0}$ is rejected. Significant test of differences in students' activeness used the Mann Whitney U Test technique. The guideline for decision making was if the scores of Asymp. Sig. (2-tailed) $>0.05$, then $\mathrm{H}_{0}$ is accepted, but if the scores of Asymp Sig (2-tailed) $<0.05$, then $\mathrm{H}_{0}$ is rejected.

\section{FINDINGS AND DISCUSSION}

\subsection{Description of Students' Activeness and Understanding of Learning Concepts by Applying the Combination CBL and Tutorial Method}

The following is the data on activeness and understanding of the concept in Figure 1 based on the effect of implementing CBL combined with the tutorial method. What is called by the combination of CBL with the tutorial method is that the steps of the core activities in learning were based on the syntax of CBL model and the syntax of the tutorial method were inserted in each activity that was carried out in the activity steps. Data from student activeness was combined with the tutorial method. It was found that the highest score was 96 , the lowest score was 61 , and the average score was 82.32 . The predicate obtained by applying this model is very high. The obtained data of students' activeness is in accordance with Nursanti's research (2014: 2) that CBL can improve students' learning outcomes in the domain of attitude and knowledge skills.

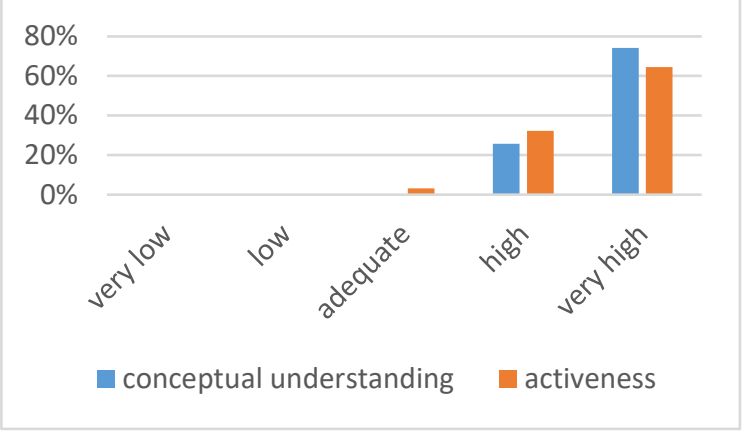

Figure 1: Data of activeness and concept understanding of experimental class 1

Data on learning activeness is obtained from the activeness observation sheet in the form of elaboration of criteria derived from activeness indicators. The activeness indicator is adopted from Sadirman's category (2011: 101); (a) Visual Activities, (b) Oral Activities, (c) Listening Activities, (d) Activistic Writing, (e) Drawing Activities, (f) Motor Activities, (g) Mental Activities and (h) Emotional Activities.

Sequentially, the total activeness score for each indicator is, (a) Visual Activities with a total score of 131, (b) Oral Activities with a total score of 108, (c) Listening Activities with a total score of 110, (d) Activistic Writing in total score 108, (e) Motor Activities with a total score of 99, (f) Mental Activities with a total score of 91 and (g) Emotional Activities with a score of 86 .

The conceptual understanding of this study is a conceptual understanding of the cognitive domain. The scoring of understanding the cognitive domain concept is taken from students' posttest. It is supported by Novitasari, L. \& Leonard's research findings (2017) that there is a significant effect between understanding the concept of mathematics learning outcomes. Therefore, this study uses posttest to assess students' conceptual understanding.

This study focuses on Basic Electricity and Electronics material on basic competency 3.12: the law of alternating current circuits in the Experimental class 1 . The application of CBL combined with the 
tutorial method shows the highest scores of 100, the lowest scores of 65 , and the average of 81,61 in the very high category. Concept understanding data that has been obtained is in accordance with Nursanti's research (2014: 2) that CBL can improve students' learning outcomes in the domain of attitude and knowledge skills.

The acquisition of this scores has increased compared to its initial ability, from an average of 50.65 to 81.61. It was concluded that CBL combined with tutorial methods can improve students' conceptual understanding. It is supported by Tsuei's (2011) statement that peer tutoring is characterized by specific role-taking which is aimed at enhancing learning, motivation and achievement. The combination of CBL with tutorial methods can also lead to students' activeness, especially visual activity, listening, oral, and writing activities. However, it does not show up on indicators of motor, mental, and emotional activities. The low scores of the indicator is caused by several factors including the application of CBL combined with tutorial methods in which students in groups and each group have tutors so students tend to wait for explanations from tutors and do not actively explore what is given from the handouts.

The improvement of students' concept comprehension skills is due to CBL combined with the tutorial method requires each group to be responsible for completing the challenges given, so that students are excited and remind each other to solve problems. The statement is in line with Qudsi's (2014) statement that group learning enables students to interact and work together to complete tasks.

\subsection{Description of Students' Activeness and Understanding of Learning Concepts by Applying the Combination of CBL and Guided Individual Method}

The following is the data on activeness and understanding of the concept in Figure 2 based on the effect of applying CBL combined with guided individual methods. What is called by the combination of CBL with guided individual methods is that the steps of the core activities in learning were made based on the syntax of CBL and the guided individual syntax method was inserted in each activity that was carried out at the activity step. Data on students' activeness was obtained from research on students applying CBL combined with the guided individual method. They obtained the highest activeness scores of 82 , the lowest scores of 61 , and the average score of 70 . The predicate obtained by applying this model is high. The data if students' activeness that has been obtained is in accordance with Nursanti's research (2014: 2) that CBL can improve student learning outcomes in the domain of attitude and knowledge skills.

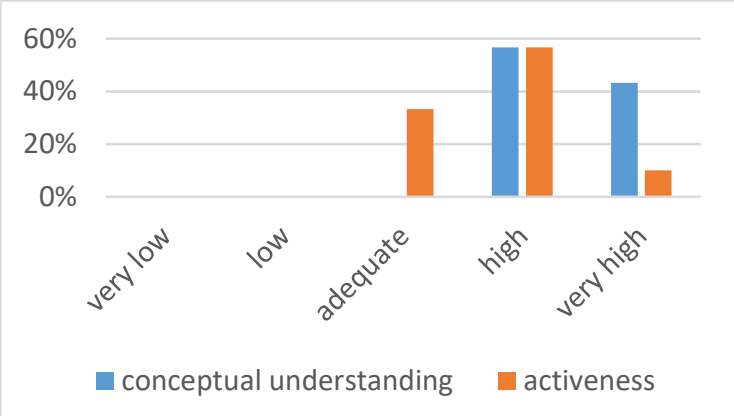

Figure 2: Data of activeness and concept understanding of experimental class 2

Data on learning activeness is obtained from activeness observation sheets made in the form of elaboration of criteria derived from activeness indicators. The activity indicator is adopted from Sadirman's category (2011: 101); (a) Visual Activities, (b) Oral Activities, (c) Listening Activities, (d) Activistic Writing, (e) Drawing Activities, (f) Motor Activities, (g) Mental Activities and (h) Emotional Activities.

Sequentially, the total activity score for each indicator is, (a) Visual Activities with a total score of 81.5, (b) Oral Activities with a total score of 89, (c) Listening Activities with a total score of 83, (d) Activitis Writing with a total score of 83, (e) Motor Activities with a total score of 76, (f) Mental Activities with a total score of 91 and (g) Emotional Activities with a score of 81.5. Based on the acquisition of a combination of CBL and individual methods, the highest score can be obtained on mental activities indicators and the lowest score are on motor activities.

The conceptual understanding of this study is a conceptual understanding of the cognitive domain. The scoring of understanding the cognitive domain concept is taken from students' posttest. It is supported by Novitasari, L. \& Leonard's research findings (2017) that there is a significant effect between understanding the concept of mathematics learning outcomes. Therefore, this study uses posttest to assess students' conceptual understanding.

This study focuses on Basic Electricity and Electronics material on basic competency 3.12: the law of alternating current circuits in the Experimental 
class 2. The application of CBL combined with guided individual methods shows the highest scores of 90 , the lowest scores of 60 , and the average of 76 in the very high category. Concept understanding data that has been obtained is in accordance with Nursanti's research (2014: 2) that CBL can improve students' learning outcomes in the domain of attitude and knowledge skills. Another research by Kastenmeier, et al (2018) finding that the individual learning plan requirement has been contribute to enchanced educational outcomes.

The acquisition of this scores has increased compared to its initial ability, from an average of 41 to 76. It was concluded that CBL combined with guided individual methods can improve students' conceptual understanding. This is because the combination $\mathrm{CBL}$ and tutorial method requires that each individual independently solve the challenge and the teacher is ready to guide students who are experiencing difficulties, so that student difficulties can be solved immediately. Meanwhile, the low scores of motor activities is caused by several factors including the application of guided individual methods where students are not brave enough to express their opinions to the teacher. Only a few students are serious and in the learning process students are required to independently solve problems.

\subsection{The Difference of Students' Activeness and Understanding of Learning Concepts between applying the Combination of $\mathrm{CBL}$ andTutorial versus the Combination of CBL and Guided Individual}

The results of understanding the concept are taken from students' posttest scores. It is in line with of Novitasari, L. \& Leonard's research findings (2017) that there is a significant effect between understanding the concept of mathematics learning outcomes. Therefore, this study uses posttest to assess students' conceptual understanding. Students' activeness scores are obtained from the activeness observation sheet which is used to score students'activity during the learning process.

The average scores of the initial ability of the experimental class 1 is 50.65 and the experimental class 2 is 41 . The activeness scores of experimental class 1 is 82 and the experimental class 2 is 70 . Meanwhile, students' scores of understanding the concept of the experimental class 1 is 82 and the experimental class 2 is 76 . The data distribution is in Figure 5.

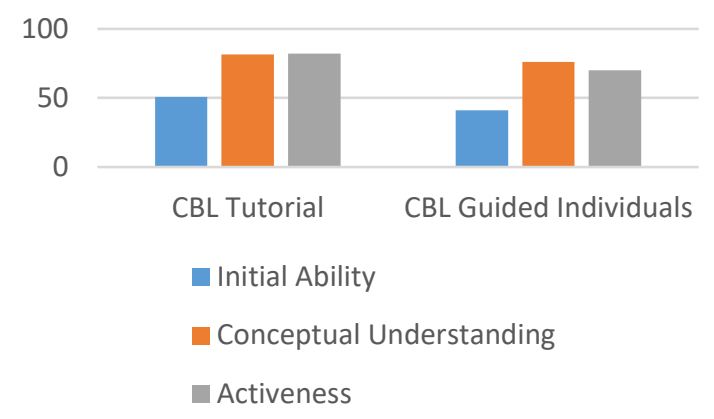

Figure 3: Scoring graphic of experimental class 1 and 2

Based on Figure 3, it can be seen that the understanding scores of the experimental class 1 concept is higher than the experimental class 2, that is 80.61 compared to 76 . Further calculations are supported by IBM SPSS Statistics 25 Software with the Independent Sample T Test method. Students' activeness data also experienced differences which were then tested using non parametric, Mann Withneyy U Test.

The analysis to examine the differences in learning outcomes of the experimental class 1 and class 2 was carried out with the $t$ test on the posttest scores of the two classes. This aims to determine the significance of differences so that they can be analyzed further. The results of the t test show sig (2tailed) 0.010 less than 0.05 , which means that there are significant differences in the results of understanding the cognitive domain concept between experimental class 1 and class 2. This is in accordance with Pertiwi's research (2018) that peer tutoring affects positively on self-efficacy and learning outcomes. The results of students' activeness data after testing show sig (2-tailed) 0,000, which means that there are significant differences between the activeness of the experimental class 1 and class 2 .

Some reasons that cause differences in the scores of students' activeness and understanding concepts are that the class applying CBL combined with the touristic method can create a comfortable classroom atmosphere for student learning. It can help in training students' sense of responsibilities for students who become tutors. Not only that, students can remind each other when some friends are lazy in order to solve challenges. Besides, students are given the freedom to express their ideas and ideas in their respective groups.

For experimental class 2 which was treated with the combination of CBL and the guided individual 
method, it was found that individual students complete challenges but there were several students ignoring them so the scores were low. Students were also embarrassed to express their difficulties to the teacher. Only a few students dared to express their difficulties so the teachers could not help maximally to those students. It, then, causes students' understanding of the concept using the combination of CBL and guided individuals methods is lower than those with the combination of $\mathrm{CBL}$ and tutorial methods. Based on the above data, it can be concluded that there are significant differences between students who learn using the combination of CBL and tutorial methods and those using the combination of CBL and guided individuals methods.

\subsection{A Combination of More Superior Method Models}

A superior model between the application of CBL combined with tutorial methods and CBL combined with guided individual methods can be seen by reviewing the scores of students' activeness and conceptual understanding in experimental class 1 and class 2. Experimental class 1 that applied $\mathrm{CBL}$ combined with tutorial methods obtained average scores in terms of activeness in a very high category (82) and in terms of conceptual understanding in a very high category as well (82). Experimental class 2 that applied CBL combined with guided individual methods obtained average scores in terms of activeness in a high category (70) and in terms of conceptual understanding in a high category as well (76).

Based on the results of activeness, it was found that the experimental class 1 had $10 \%$ higher scores than the experimental class 2 . It can be concluded that the application of CBL combined with tutorial methods is superior to the application of CBL combined with individual methods in terms of students' activeness.

The findings of this study are in line with the research by Ardyansyah (2011) that learning with peer tutoring methods is superior in improving learning achievement than the demonstration learning method. Another study by Soraya (2017) shows that through peer tutoring learning can lead to enthusiasm for completing the case studies presented. A research by Muslikhoh (2016) also states that there is a positive influence on the application of peer tutoring learning to students' conceptual understanding during learning compared to individual models.

\section{CONCLUSION}

1. TIPTL class $X$ students of SMKN 1 Kediri who applied CBL combined with guided individual methods obtained the results of activeness with the highest score of 82 and the lowest score of 61 with an average score of 70 , where the results included in a high category. In terms of conceptual understanding, the results show the highest score of 90 and the lowest score of 60 with an average score of 76 , where the results are included in a high category.

2. TIPTL class $X$ students of SMKN 1 Kediri who applied CBL combined with the tutorial methods obtained the results of activeness with the highest score of 96 and the lowest score of 61 with an average score of of 82 , where the results were included in a very high category. In terms of conceptual understanding, the results show the highest score of 100 and the lowest score of 65 with an average score of 82 , where the results are included in a very high category.

3. There is a significant difference between the classes applying CBL combined with guided individual methods and classes applying CBL combined with the tutorial methods on students' activeness and conceptual understanding; a significance level of 0,000 for students' activeness and a significance level of 0.010 for conceptual understanding.

4. The combination of CBL and the tutorial methods is superior to the combination of $\mathrm{CBL}$ and the guided individual methods seen from conceptual understanding with the same increasing presentation score of $35 \%$, yet the results of activeness are superior, 82 compared to 70 .

\section{SUGGESTIONS}

1. For students, it is hoped that they will continue to be active in learning so that they can improve students 'understanding of concepts, as well as to improve students' soft skills.

2. For teachers, the application of CBL combined with guided individual or tutorial methods will require more time because of the syntax of CBL itself. Therefore, it is very helpful to have good time management to apply this model.

3. For further researchers, there is a need for a careful preparation before conducting research such as conditioning laboratory equipment. It should be noted in making calculation kind of 
questions, use numbers that do not need tools to count. If the concern in questions related to story, use language that is easy for students to understand.

\section{REFERENCES}

Asmawi, W., Arnentis, \& Fauziah, Y. (2014). Profil Keterampilan Abad Ke-21 (21st Century Skills) Mahasiswa Pada Perkuliahan Teknik dan Manajemen Laboratorium Program Studi Pendidikan Biologi Fkip Universitas Riau. Universitas Riau. Retrieved December 1, 2018, from (https://ejournal.unrl.ac.id/index.php/JPSB/article/vie w/5128.)

Demircioğlu, G., \& Yadigaroğlu, M. (2014). A Comparison of Level of Understanding of Student Teachers and High School Students Related to the Gas Concept. Procedia - Social and Behavioral Sciences, 116, 28902894.

Hikmah, M., Santoso, D., \& Subarno A. (2015). Pengaruh Keaktifan Siswa Dalam Pembelajaran dan Praktek Kerja Lapangan Terhadap Kemampuan Komunikasi Interpersonal Siswa Kelas XII Jurusan Administrasi Perkantoran SMK Negeri 1 Surakarta. Unpublished Undergraduate Thesis. Surakarta: Faculty of Teacher Training and Education, Universitas Sebelas Maret.

Kastenmeier, A. S., Redlich, P. N., Fihn, C., Treat, R., Chou, R., Homel, A., \& Lewis, B. D. (2018). Individual learning plans foster self-directed learning skills and contribute to improved educational outcomes in the surgery clerkship. The American Journal of Surgery, 216, 160-166.

Ministry of Education and Culture, Pergeseran Paradigma Belajar Abad 21, Badan Penelitian dan Pengembangan, Ministry of Education and Culture. Retrieved November 1, 2018, from (http://litbang.kemdikbud.go.id/site/index.php/home24/233-pergeseran-paradigma-belajar-abad21),

Novitasari, Lilis dan Leonard. (2017). Pengaruh Kemampuan Pemahaman Konsep Matematika Terhadap Hasil Belajar Matematika. Retrieved March 14, 2019, from (https://www.researchgate.net/profile/Leonard Leonar d2/publication/321824137_Pengaruh_Kemampuan_Pe mahaman_Konsep_Matematika_Terhadap_Hasil_Bela jar_Matematika/links/5a3348cbaca2727144b6600f/Pe ngaruh-Kemampuan-Pemahaman-Konsep

Matematika-Terhadap-Hasil-Belajar-

Matematika.pdf?origin=publication_detail).

Nursanti, R., Kriswandani, \& Yunianta, T. N. H. (2014). Pengaruh Challenge Based Learning terhadap Hasil Belajar Matematika Siswa Kelas IX SMP Negeri 1 Getasan Kabupaten Semarang. 1-6. Retrieved December 1, 2018, from (http://repository.uksw.edu/bitstream/123456789/5636 12/TI_202010099_Abstract.pdf.)
Qudsi, I. 2014. Pembelajaran Tutor Sebaya Materi Besaran dan Satuan Fisika. Jurnal Pendidikan Tindakan Kelas, 4, 1-10.

Regulation of the Ministry of Education and Culture No. 20 of 2003 concerning the National Education System. Retrieved November 4, 2018, from (https://kelembagaan.ristekdikti.go.id/wpcontent/uploa ds/2016/08/UU_no_20_th_2003.pdf).

Sadirman. (2011). Interaksi dan Motivasi Belajar Mengajar. PT Raja Grafindo Persada. Jakarta.

Soraya, D. U. 2017. Growing Motivation Learning of Matrix Through Peer Tutoring Learning. Jurnal Icovet, 116, 133-137.

Suliyanto. 2014. Statistik Non Parametrik. C.V. Andi Offset . Yogyakarta.

Susilo, H. (2011). Blended Learning untuk Menyiapkan Siswa Hidup di Abad 21. Makalah disajikan dalam Seminar Nasional Pengembangan Pembelajaran Berbasis Blended Learning. Biology Department Student Association "Lebah Madu", Universitas Negeri Malang. Malang, 13 November 2011.

Tsuei, M. 2012. Using synchronous peer tutoring system to promote elementary students' learning in mathematics. Computers \& Education, 58, 1171-1182.

Walters, B., Potetz, J., \& Fedesco, H. N. 2017. Simulations in the Classroom: An Innovative Active Learning Experience. Clinical Simulation in Nursing, 13, 609615

Yang, Z., Zhou, Y., Chung, J. W. Y., Tang, Q., Jiang, L., \& Wong, T. K. S. 2018. Challenge Based Learning nurtures creative thinking: An evaluative study. Nurse Education Today, 71, 40-47. 